\title{
Milk production and energy efficiency of Holstein and Jersey-Holstein crossbred dairy cows offered diets containing grass silage
}

\author{
B. Xue, ${ }^{*} \dagger$ T. Yan,${ }^{1}$ C. F. Ferris, $\dagger$ and C. S. Mayne \\ *Low Carbon Animal Science and Technology Research Centre, Sichuan Agricultural University, Yaan, Sichuan, 625014, China \\ †Agri-Food and Biosciences Institute, Hillsborough, Co. Down BT26 6DR, United Kingdom
}

\begin{abstract}
Eight Holstein and 8 Jersey-Holstein crossbred dairy cows (all primiparous) were used in a repeated 2 (genotype) $\times 2$ (concentrate level) factorial design study involving a total of 4 periods (each of 6 -wk duration), designed to examine the effect of cross-breeding on the efficiency of milk production and energy use. The 4 periods began at 5, 11, 27, and 33 wk of lactation, respectively. Animals were offered a completely mixed diet containing grass silage and concentrates, with the level of concentrate in the diet either 30 or $70 \%$ of dry matter (DM). During the final $10 \mathrm{~d}$ of each period, ration digestibility and energy use was measured, the latter in indirect open-circuit respiration calorimeters. No significant interaction existed between cow genotype and dietary concentrate level for feed intake, milk production, or any of the energy use parameters measured. Across the 2 genotypes, total DM intake, milk yield, and milk protein and lactose concentrations increased with increasing dietary concentrate level. Thus, cows offered the high-concentrate diet had a higher gross energy (GE) intake, and a higher energy output in feces, urine, milk as heat, and a higher metabolizable energy (ME) intake as a proportion of GE intake and as a proportion of digestible energy intake. Across the 2 levels of concentrates, the Jersey-Holstein cows had a significantly higher total DM intake and body condition score, and produced milk with higher fat, protein, and energy concentrations, compared with those of the Holstein cows. In addition, the Jersey-Holstein cows had a significantly higher GE intake and energy output in urine, methane, and milk. However, crossbreeding had no significant effect on energy digestibility or metabolizability, energy partitioning between milk and body tissue, or the efficiency of ME use for lactation. Relating ME intake to milk energy output and heat production indicated that crossbreeding did not influence
\end{abstract}

Received July 29, 2010.

Accepted November 12, 2010.

${ }^{1}$ Corresponding author: tianhai.yan@afbini.gov.uk
ME requirement for maintenance or energy efficiencies. The energy metabolism data were also used to compare energy efficiencies between "early" (data pooled for the first 2 periods) and "late" (data pooled for the second 2 periods) stages of lactation. Stage of lactation had no effect on energy digestibility or metabolizability, whereas increasing stage of lactation increased the rate of energy partitioning into body tissue and reduced the rate of energy partitioning into milk, irrespective of cow genotype. In conclusion, crossbreeding of Holstein dams with Jersey sires had no adverse effects on the overall production efficiency of Holstein dairy cows in terms of milk production, efficiency of ME use for lactation, and energy partitioning between milk and body tissue.

Key words: energy use, Holstein cow, Jersey-Holstein cow, milk production

\section{INTRODUCTION}

Historically, selection programs within the Holstein breed have focused on milk production at the expense of functional traits such as fertility, health, and longevity. Although milk yields within the Holstein population have increased, clear evidence exists of declining fertility levels (Lucy, 2001; Pryce et al., 2004; Mackey et al., 2007). In addition, levels of inbreeding within many Holstein populations continue to increase (Hansen, 2000). This decrease in functional traits within the Holstein population has prompted an increased interest in crossbreeding as a means of improving cow fertility, health, and longevity traits. The benefits of crossbreeding include heterosis, and the potential to introduce desirable traits from another breed. Several breeds have been used as sires on Holstein cows within recent crossbreeding programs, including the Scandinavian Red, Montbeliarde, Normande (Heins et al., 2006), and Jersey (Auldist et al., 2007: Prendiville et al., 2010), with clear benefits in terms of milk composition and fertility having been reported. Whereas some studies have reported differences between purebred and crossbred dairy cattle in terms of body tissue reserve, little detailed information is available on the effect of crossbreeding on the efficiency of energy use for lactation. 
Table 1. Experimental design ${ }^{1}$

\begin{tabular}{|c|c|c|c|c|}
\hline \multirow[b]{2}{*}{ Period } & \multirow{2}{*}{$\begin{array}{l}\text { Weeks of } \\
\text { lactation }\end{array}$} & \multicolumn{3}{|c|}{ Dietary concentrate level (DM basis) } \\
\hline & & $50 \%$ & $30 \%$ & $70 \%$ \\
\hline Pre-experiment & $1-4$ & All cows & & \\
\hline Period 1 & $5-10$ & & $\mathrm{H} 1+\mathrm{JH} 1$ & $\mathrm{H} 2+\mathrm{JH} 2$ \\
\hline Period 2 & $11-16$ & & $\mathrm{H} 2+\mathrm{JH} 2$ & $\mathrm{H} 1+\mathrm{JH} 1$ \\
\hline Nonexperimental period & $16-26$ & All cows & & \\
\hline Period 3 & $27-32$ & & $\mathrm{H} 1+\mathrm{JH} 1$ & $\mathrm{H} 2+\mathrm{JH} 2$ \\
\hline Period 4 & $33-38$ & & $\mathrm{H} 2+\mathrm{JH} 2$ & $\mathrm{H} 1+\mathrm{JH} 1$ \\
\hline
\end{tabular}

The efficiency with which energy is used for lactation is a key driver of production efficiency. For example, Veerkamp and Emmans (1995) found that high genetic merit Holstein dairy cows had the capacity to partition more energy into milk and less into body tissue, in comparison with medium genetic cows. Similarly, Yan et al. (2006) reported that Holstein dairy cows partitioned more energy into milk and less into body tissue than did Norwegian dairy cows during early lactation, although this difference disappeared during late lactation. In beef cattle, Frisch and Vercoe (1984) also reported that maintenance energy requirements varied according to the production potential of different beef cattle breeds. However, little information is available in the literature on the effect of crossbreeding on energy efficiencies and energy partitioning between milk and body tissue. Indeed, for Jersey crossbred cows, one of the most popular dairy cow crosses on dairy farms in many countries, virtually no information is available on the relative intake potential of Holstein and Jersey-Holstein crossbred cows within confinement systems. One exception is the study by Heins et al. (2008) in which neither food intake or feed efficiency differed between Holstein and Jersey-Holstein crossbred cows. However, within this study, feed efficiency was expressed as the ratio of fat + protein yield divided by DM intake and ECM yield divided by DM intake. No study has been identified in which nutrient digestion and detailed energy use of Holstein and Jersey-Holstein cows have been compared. Thus, the objective of the present study was to examine the efficiency of energy use of Holstein and Jersey-Holstein dairy cows offered mixed diets of grass silage with 2 levels of concentrates. The second objective was to evaluate the effects of stage of lactation on energy efficiencies within each cow genotype.

\section{MATERIALS AND METHODS}

\section{Animal, Diet, and Experimental Design}

Eight Holstein and 8 Jersey-Holstein crossbred dairy cows (all primiparous) were used in a repeated
2 (genotype) $\times 2$ (concentrate level) factorial design study, with a total of 4 periods (each of 6 -wk duration). Holstein cows were selected from a high genetic merit herd at the Agri-Food and Biosciences Institute (Hillsborough, Co. Down, UK) and their annual milk yield (305 d) obtained after the present study was, on average, 6,011 (SD 1,011.8) kg. The corresponding value for Jersey Holstein was 6,105 (SD 673.8) kg. From calving until approximately $28 \mathrm{~d}$ postcalving, cows were offered a standard complete diet comprising grass silage and concentrates (proportionally 0.5:0.5, DM basis). Thereafter, for the next 6 wk (period 1), one-half of the cows within each genotype (group 1) were offered a diet containing a high proportion of concentrates (proportionally 0.7 concentrates and 0.3 grass silage, on a DM basis), whereas the remaining cows (group 2) were offered a diet containing a low proportion of concentrates (proportionally 0.3 concentrates and 0.7 grass silage, on a DM basis). Cows within each genotype were allocated to either group 1 or group 2 so that groups were balanced for calving date, BW, milk yield, and BCS. During period 2, the diets offered to the group 1 and group 2 cows of each genotype were reversed. On completion of period 2, all cows were offered the standard diet (described previously) for a 10-wk nonexperimental period. From approximately wk 27 of lactation onwards, the experimental design was repeated during a third and fourth period. The experimental design is presented in Table 1.

The concentrate offered consisted of $170 \mathrm{~g}$ of barley/ $\mathrm{kg}, 170 \mathrm{~g}$ of wheat $/ \mathrm{kg}, 170 \mathrm{~g}$ of molassed sugar beet pulp/kg, $170 \mathrm{~g}$ of citrus pulp/kg, $230 \mathrm{~g}$ of soybean meal/ $\mathrm{kg}, 70 \mathrm{~g}$ of rapeseed meal $/ \mathrm{kg}$, and $20 \mathrm{~g}$ of molasses $/ \mathrm{kg}$ (air dry basis), and contained $880 \mathrm{~g}$ of $\mathrm{DM} / \mathrm{kg}, 18.3 \mathrm{MJ}$ of gross energy $(\mathbf{G E}) / \mathrm{kg}$ of DM, and 57, 228, 118, and $200 \mathrm{~g} / \mathrm{kg}$ of DM of ash, CP, ADF, and NDF, respectively. In addition, each cow was supplemented with $140 \mathrm{~g} / \mathrm{d}$ of a mineral/vitamin premix. All rations were mixed daily using a complete diet mixer wagon. The silage offered throughout the experiment was produced from the primary growth of a perennial ryegrass-based 
sward. In order to ensure that the quality of the silage offered during the final $10 \mathrm{~d}$ of each of the 4 experimental periods was of a consistent composition, sufficient silage for each of these periods was frozen in thin layers in polythene bags (approximately $200 \mathrm{~kg} / \mathrm{bag}$ ) at the beginning of the first period. This allowed silage to be thawed rapidly (within $48 \mathrm{~h}$ ) for subsequent feeding. The silage had a $\mathrm{pH}$ of 3.77 , an ammonia $\mathrm{N}$ content of $8 \%$ of total $\mathrm{N}$, a DM content of $288 \mathrm{~g} / \mathrm{kg}$, a GE content of $18.1 \mathrm{MJ} / \mathrm{kg}$ of DM and an ash, CP, ADF, and NDF content of 94, 161, 276, $477 \mathrm{~g} / \mathrm{kg}$ of DM, respectively.

Fresh food was offered daily at approximately $1000 \mathrm{~h}$, with food offered at proportionally 1.1 of the previous day's intake. All cows were allowed free access to drinking water, and were milked twice daily commencing at approximately 0700 and $1530 \mathrm{~h}$. During the first 31 d of each experimental period, cows were housed in cubicle accommodation as a single group, with access to the specified diet controlled via an electronic Calan gate feeding system. Cows were then transferred in pairs (one of each genotype) to a metabolism unit and tied individually in stalls with free access to drinking water. Each nutrient utilization trial encompassed an 8 -d period (6-d feeding period commencing $2 \mathrm{~d}$ before the first collection of feces and urine) and a 6-d total feces and urine collection period. Feces were collected in a plastic collection tray $(96 \times 108 \times 36 \mathrm{~cm})$ placed behind each cow. Urine was collected in a 25 -L plastic container via a flexible plastic tube, which was attached to a urine separation system. This was held in position over the vulva by attaching it using a "hook and loop" self-adhesive fastening tape to a patch glued on either side of the cow's tail head. Afterward, cows were placed in indirect open-circuit respiration calorimeter chambers for $3 \mathrm{~d}$, with gaseous exchange measured during the final $48 \mathrm{~h}$. The procedure of measurements and calibration of the chambers have been reported by Gordon et al. (1995a) and Yan et al. (2000), respectively. Heat production was calculated using the equation of Brouwer (1965). During the 8-d period in the metabolism unit and the 3 -d period in the respiration chambers, diets were prepared individually in a mini mixer using the thawed silage as described previously.

\section{Measurements}

Throughout the experiment, total food intake for each individual cow was recorded daily, either electronically using a Calan gate feeding system (when in cubicle accommodation), or as the difference between food offered and the uneaten component of the diet (during the period in the metabolism unit and calorimeter chambers). Fresh silage offered was sampled daily, with a subsample analyzed for oven $\mathrm{DM}$ content $\left(85^{\circ} \mathrm{C}\right.$ for $24 \mathrm{~h}$ ), whereas a second subsample was dried at $60^{\circ} \mathrm{C}$ for $48 \mathrm{~h}$. These latter samples were either bulked weekly during the first $4 \mathrm{wk}$ of each period, or kept as individual samples during the final $11 \mathrm{~d}$ of each period when energy metabolism data were measured in the metabolism unit and calorimeter chambers. These bulked or individual day samples were subsequently used for determination of ADF, NDF, ash, and water-soluble carbohydrates concentrations. Twice weekly during the first 4 wk of each period and daily during the final 11 $\mathrm{d}$ of each period, an additional fresh silage sample was taken for determination of concentrations of GE, CP, and fermentation variables ( $\mathrm{pH}$, ammonia, VFA, lactic acid, and alcohol). Samples of concentrates were taken weekly during the first $4 \mathrm{wk}$ of each period and daily during the final $11 \mathrm{~d}$ of each period; these samples were used for analysis of oven DM, GE, N, ADF, NDF, and ash concentrations.

Feces and urine outputs of cows during the final 6 $\mathrm{d}$ in the metabolism unit were recorded and sampled daily as a proportion (5\%) of total excretion of feces (by weight) and urine (by volume). The 6-d samples of feces and urine were separately mixed and a representative sample taken for analysis as follows: feces samples were analyzed for oven DM, N, GE, ADF, NDF, and ash concentrations and urine samples were analyzed for GE and N concentrations. The methods adopted for analysis of silage, concentrate, feces, and urine samples were as described by Mayne and Gordon (1984). Crude protein concentration was determined as Kjeldahl $\mathrm{N} \times$ 6.25 .

Milk yields were recorded daily at each milking throughout the experiment. Milk composition (fat, protein, lactose, and energy) was determined on a weekly basis from one consecutive a.m. and p.m. milking during the first $4 \mathrm{wk}$ of each period, and on a daily basis during the digestibility and chamber measurement period. Separate analysis was completed for a.m. and p.m. samples, and a weighted milk composition for the 24-h sampling period was calculated on the basis of recorded a.m. and p.m. milk yields. Milk composition was determined using an infrared milk analyzer. Live weight and BCS of the cattle were determined weekly. Body condition of each cow was assessed on a scale of 1 (very thin) to 5 (very fat; Mulvany, 1977).

\section{Statistical Analyses}

The effects of cow genotype and concentrate level on DM intake, live weight, BCS, milk production, energy intake and outputs, and energy efficiencies were analyzed using 2-way (cow genotype vs. concentrate level) 
Table 2. Effects of cow genotype and nutritional level on animal performance

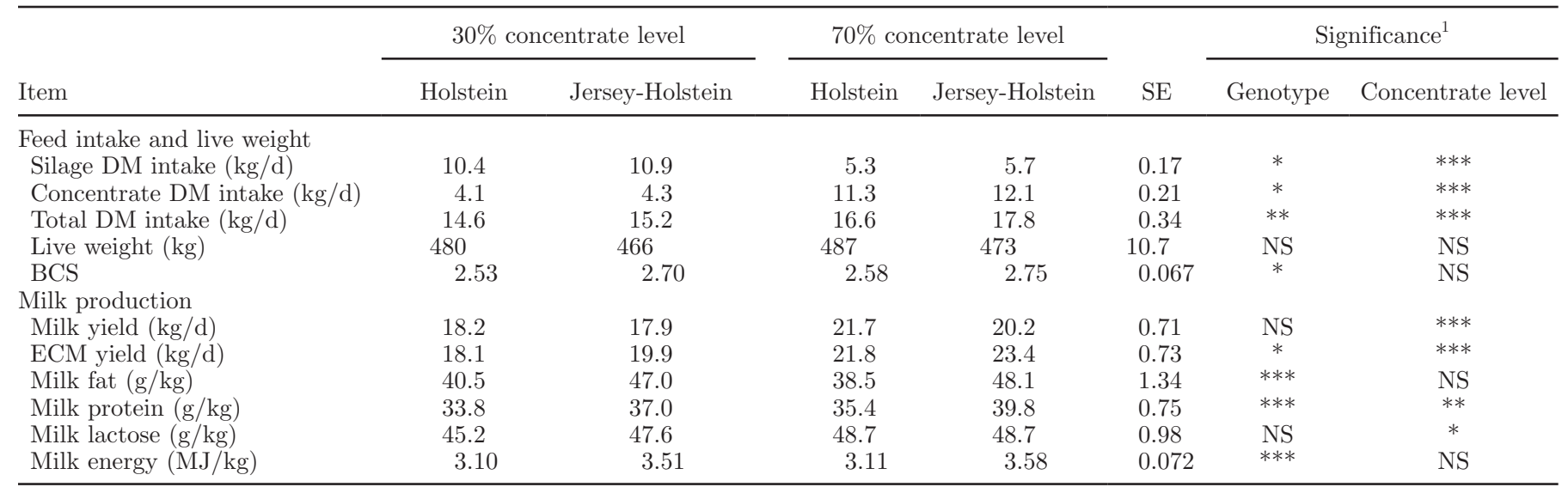

${ }^{1}$ No significant interaction existed for any variable between cow genotype and concentrate level.

${ }^{*} P<0.05 ;{ }^{* *} P<0.01 ;{ }^{* * *} P<0.001$.

ANOVA with experimental period as blocking. The effects of stage of lactation within each cow genotype and interactions between stage of lactation and cow genotype were also undertaken using 2-way ANOVA with cow pair as blocking (discussed later). The linear regression technique of $\mathrm{ME}$ intake against milk energy output or heat production (HP) was used to examine effects of cow genotype on energy use efficiency. The statistical program used in the present study was Genstat 6.1 (6th edition; Lawes Agricultural Trust, Rothamsted, UK).

Energy-corrected milk yield $(\mathrm{kg} / \mathrm{d})$ was calculated as total milk energy output (MJ/d) divided by milk energy concentration of $1 \mathrm{~kg}$ of standard milk (3.1 MJ/ $\mathrm{kg}$; fat, protein, and lactose concentrations $=40,32$, and $48 \mathrm{~g} / \mathrm{kg}$, respectively).

The efficiency of ME use for lactation $\left(k_{l}\right)$ was calculated as

$$
k_{l}=\frac{E_{l}+a E_{g}}{\mathrm{MEI}-\mathrm{ME}_{\mathrm{m}}},
$$

where $E_{g}=$ tissue energy balance $(\mathrm{MJ} / \mathrm{d}) ; E_{l}=$ milk energy output $(\mathrm{MJ} / \mathrm{d}) ; \mathrm{MEI}=\mathrm{ME}$ intake $(\mathrm{MJ} / \mathrm{d}) ; \mathrm{ME}_{\mathrm{m}}$ $=\mathrm{ME}$ requirement for maintenance $(\mathrm{MJ} / \mathrm{d})$ estimated from the present study; $a=0.84$ if $E_{g}<0$, or $a=0.95$ if $E_{g}>0$ (AFRC, 1990).

\section{RESULTS}

No significant interaction existed between cow genotype and concentrate feed level for feed intake, milk production, energy intake, energy output, or energy efficiency. Thus, the main effects of cow genotype and concentrate feed levels are presented in this paper.

\section{Feed Intake and Animal Performance}

Increasing the concentrate proportion in the diet from 30 to $70 \%$ produced a significant increase in total DM intake, milk yield, ECM yield $(P<0.001)$, and protein $(P<0.01)$ and lactose $(P<0.05)$ concentration in milk (Table 2). However, dietary concentrate level had no significant effect on live weight, BCS, or the fat or energy concentration of milk. Across the 2 dietary concentrate levels, Jersey-Holstein cows had significantly higher silage, concentrate $(P<0.05)$, and total DM intakes $(P<0.01)$, and a higher BCS $(P<0.05)$, than did the Holstein cows, whereas live weight was similar between the 2 genotypes. Whereas milk yield was not affected by genotypes $(P>0.05)$, Jersey-Holstein cows had a significantly higher ECM yield $(P<0.05)$, a reflection of the higher fat and protein concentrations in the milk of the Jersey-Holstein cows $(P<0.001)$. Cow genotypes had no significant effect on milk lactose concentration.

\section{Energy and Nutrient Digestibility}

No significant effects of either cow genotype or concentrate level existed on DM, OM, energy, or nitrogen digestibility (Table 3). Although digestible OM in total DM was unaffected by cow genotype, it was higher with the diet containing the high concentrate level $(P$ $<0.05)$.

\section{Energy Intake and Output, and Efficiency of Energy Use}

Across the 2 cow genotypes, increasing dietary concentrate level significantly increased GE intake, HP, and energy outputs in feces $(P<0.001)$, urine $(P<$ 
Table 3. Effects of cow genotype and nutritional level on energy and nutrient digestibility

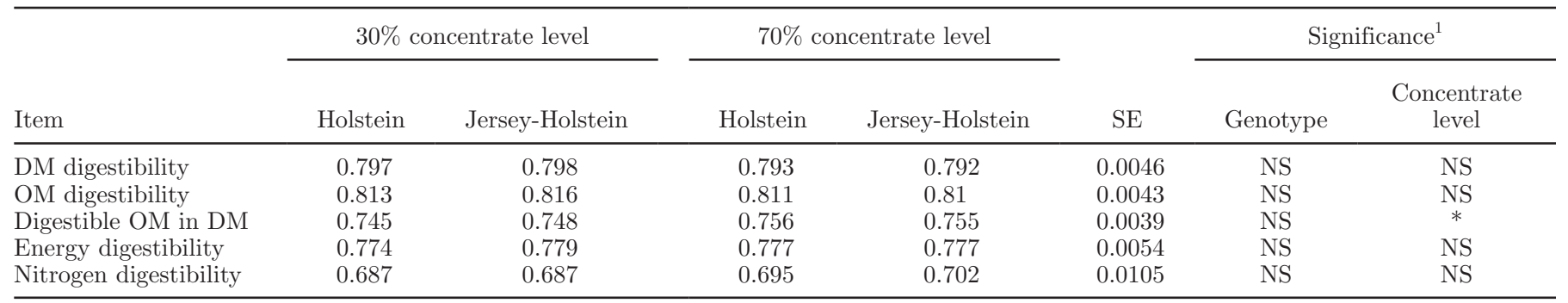

${ }^{1}$ No significant interaction existed for any variable between cow genotype and concentrate level.

$* P<0.05$.

$0.01)$, and milk $(P<0.001)$, but had no significant effects on methane energy output or energy balance (Table 4). Cows offered the high dietary concentrate level had a significantly higher ME/GE $(P<0.05)$ and $\mathrm{ME} /$ digestible energy $(\mathbf{D E} ; P<0.001)$ across the 2 genotypes. However, dietary concentrate level had no significant $(P>0.05)$ effect on energy partitioning between milk (milk energy/ME intake) and body tissue (energy balance/ME intake) or $k_{l}$. Across dietary concentrate levels, Jersey-Holstein cows had a significantly higher GE intake, urinary energy output, methane energy emission, and milk energy output $(P<0.05)$, and lower $\mathrm{HP} / \mathrm{ME}$ intake $(P<0.05)$ than did Holstein cows. However, cow genotype had no significant effects on fecal energy output, HP, or energy balance. In addition, cow genotype had no significant effects on $\mathrm{DE} / \mathrm{GE}, \mathrm{ME} / \mathrm{GE}, \mathrm{ME} / \mathrm{DE}, k_{l}$, or energy partitioning between milk (milk energy/ME intake) and body tissue (energy balance/ME intake).
Because no significant interaction was found between cow genotype and concentrate level for any variable examined, energy metabolism data from the 2 concentrate levels within each genotype were pooled and used to develop relationships between ME intake and HP and milk energy output. These relationships are presented in Table 5 and Figure 1, and were used to examine effects of cow genotype on energy efficiency. In order to examine the effect of genotype on these relationships, each pair of relationships was developed with a common coefficient and different constants. All relationships were significant $(P<0.001)$. No significant difference was found in constants in any pair of relationships between the 2 genotypes (Eq. 1a vs. 1b, $2 \mathrm{a}$ vs. $2 \mathrm{~b}, 3 \mathrm{a}$ vs. $3 \mathrm{~b}$, and $4 \mathrm{a}$ vs. $4 \mathrm{~b}$; Table 5 ). The constants in each pair of relationships were similar. The $\mathrm{ME}_{\mathrm{m}}$ calculated from equations $1 \mathrm{a}$ and $1 \mathrm{~b}$ were similar between Holstein and Jersey-Holstein dairy cows (0.71 vs. $\left.0.67 \mathrm{MJ} / \mathrm{kg}^{0.75}\right)$. These findings support the results

Table 4. Effects of cow genotype and nutritional level on energy intake and outputs and energy efficiencies

\begin{tabular}{|c|c|c|c|c|c|c|c|}
\hline \multirow[b]{2}{*}{ Item $^{1}$} & \multicolumn{2}{|c|}{$30 \%$ concentrate level } & \multicolumn{2}{|c|}{$70 \%$ concentrate level } & \multirow[b]{2}{*}{ SE } & \multicolumn{2}{|c|}{ Significance $^{2}$} \\
\hline & Holstein & Jersey-Holstein & Holstein & Jersey-Holstein & & Genotype & $\begin{array}{c}\text { Concentrate } \\
\text { level }\end{array}$ \\
\hline \multicolumn{8}{|c|}{ Energy intake and output (MJ/d) } \\
\hline GE intake & 269.0 & 280.3 & 306.0 & 328.1 & 6.59 & $*$ & $* * *$ \\
\hline Fecal energy & 60.7 & 62.1 & 68.1 & 73.5 & 2.16 & $\mathrm{NS}$ & $* * *$ \\
\hline Urinary energy & 9.8 & 10.5 & 10.7 & 11.7 & 0.39 & $*$ & $* *$ \\
\hline Methane energy & 18.9 & 19.9 & 18.4 & 19.9 & 0.49 & $*$ & NS \\
\hline $\mathrm{HP}$ & 116.0 & 118.6 & 134.0 & 133.7 & 2.57 & $\mathrm{NS}$ & $* * *$ \\
\hline Milk energy & 56.0 & 62.2 & 66.9 & 72.2 & 2.23 & $*$ & $* * *$ \\
\hline Energy balance & 7.5 & 7.0 & 7.8 & 17.1 & 3.80 & $\mathrm{NS}$ & NS \\
\hline \multicolumn{8}{|l|}{ Energy use } \\
\hline $\mathrm{DE} / \mathrm{GE}$ & 0.774 & 0.779 & 0.777 & 0.777 & 0.0054 & NS & NS \\
\hline $\mathrm{ME} / \mathrm{GE}$ & 0.667 & 0.670 & 0.681 & 0.680 & 0.0059 & $\mathrm{NS}$ & $*$ \\
\hline $\mathrm{ME} / \mathrm{DE}$ & 0.861 & 0.860 & 0.876 & 0.876 & 0.0034 & NS & $* * *$ \\
\hline $\mathrm{HP} / \mathrm{ME}$ intake & 0.650 & 0.637 & 0.647 & 0.602 & 0.0119 & $*$ & NS \\
\hline Milk energy/ME intake & 0.314 & 0.336 & 0.326 & 0.328 & 0.0108 & $\mathrm{NS}$ & NS \\
\hline Energy balance/ME intake & 0.037 & 0.027 & 0.027 & 0.070 & 0.0191 & NS & NS \\
\hline$k_{l}$ & 0.604 & 0.575 & 0.562 & 0.581 & 0.0143 & $\mathrm{NS}$ & NS \\
\hline
\end{tabular}

${ }^{1} \mathrm{HP}=$ heat production; $\mathrm{DE}=$ digestible energy; $\mathrm{GE}=$ gross energy; $k_{l}=$ efficiency of $\mathrm{ME}$ use for lactation.

${ }^{2}$ No significant interaction existed for any variable between cow genotype and concentrate level.

${ }^{*} P<0.05 ;{ }^{* *} P<0.01 ;{ }^{* * *} P<0.001$. 
Table 5. Comparison of constants between Holstein and Jersey-Holstein dairy cows in linear regression equations of ME intake against heat production (HP) and milk energy output ${ }^{1}$

\begin{tabular}{|c|c|c|c|}
\hline Genotype & Equation $^{2}$ & $r^{2}$ & Equation no. \\
\hline Holstein & $\mathrm{E}_{1(0)}=0.581_{(0.0393)}$ MEI $-0.413_{(0.0753)}$ & 0.81 & $1 \mathrm{a}$ \\
\hline Jersey-Holstein & $\mathrm{E}_{1(0)}=0.581_{(0.0393)}$ MEI $-0.3866_{(0.0815)}$ & & $1 b$ \\
\hline Holstein & $\mathrm{HP}=0.416_{(0.0417)} \mathrm{MEI}+0.433_{(0.0799)}$ & 0.63 & $2 \mathrm{a}$ \\
\hline Jersey-Holstein & $\mathrm{HP}=0.416{ }_{(0.0417)} \mathrm{MEI}+0.409{ }_{(0.0865)}$ & & $2 \mathrm{~b}$ \\
\hline Holstein & $\mathrm{HP} / \mathrm{MEI}=-0.114_{(0.0216)} \mathrm{MEI}+0.864_{(0.0414)}$ & 0.37 & $3 \mathrm{a}$ \\
\hline Jersey-Holstein & $\mathrm{HP} / \mathrm{MEI}=-0.114_{(0.0216)} \mathrm{MEI}+0.854_{(0.0448)}$ & & $3 \mathrm{~b}$ \\
\hline Holstein & $\left(\mathrm{HP}-\mathrm{ME}_{\mathrm{m}}\right)=0.416_{(0.0417)} \mathrm{MEI}-0.278_{(0.0799)}$ & 0.66 & $4 \mathrm{a}$ \\
\hline Jersey-Holstein & $\left(\mathrm{HP}-\mathrm{ME}_{\mathrm{m}}\right)=0.416_{(0.0417)} \mathrm{MEI}-0.255_{(0.0865)}$ & & $4 \mathrm{~b}$ \\
\hline
\end{tabular}

${ }^{1}$ No significant difference existed for constants in any pair of the relationships; values in subscript parentheses are SE data.

${ }^{2}$ The unit for all variables of energy intake and output $=\mathrm{MJ} / \mathrm{kg}^{0.75} ; \mathrm{E}_{1(0)}=$ milk energy output adjusted to zero energy balance; $\mathrm{HP}=$ heat production; $\mathrm{MEI}=\mathrm{ME}$ intake; $\mathrm{ME}_{\mathrm{m}}=\mathrm{ME}$ requirement for maintenance $(\mathrm{MJ} / \mathrm{d})$, estimated respectively from the present Eq. 1a and 1b for Holstein and Jersey-Holstein cows.

presented in Table 4 that the efficiency of ME use was not affected by genotype.

\section{DISCUSSION}

Ample evidence exists in the literature indicating that within a breed of dairy cow, ME intake, milk production, and energy digestibility and metabolizability increase with increasing dietary concentrate proportions. Consequently, the present discussion will focus on the effects of cow genotype and stage of lactation on milk production efficiency and energy use.

\section{Effects of Cow Genotype on Energy Use Efficiency}

Food intake is positively related to levels of milk production in dairy cows. However, few studies have compared the food intake of Holstein and Jersey-Holstein dairy cows within a confinement situation. One exception is the study by Heins et al. (2008), which also involved primiparous cows, and in which genotype had no effect on food intake or fat and protein yield. Whereas the higher intake of the Jersey-Holstein cows in the present study is perhaps unexpected, the crossbred cows were similar in live weight to the Holstein cows, in contrast to the study by Heins et al. (2008) in which the crossbred cows were approximately $30 \mathrm{~kg}$ lighter. Although milk yield was unaffected by genotype in the current study, the Jersey-Holstein cows produced milk with a higher concentration of fat and protein and as such they had a higher ECM yield than did the Holstein cows. A similar result was also reported by Prendiville et al. (2009), who found that Jersey-Holstein cows produced a marginally higher fat and protein yield than did pure Holstein cows during a whole lactation period. Nevertheless, in the present study, the gross efficiency of ME use, when expressed as milk energy output as a proportion of ME intake, did not differ significantly between the 2 cow genotypes. Heins et al. (2008) also reported that the feed efficiency for d 4 to 150 of lactation was similar for Jersey-Holstein and pure Holstein cows. In a modeling analysis, Schwager-Suter et al. (2001) observed greater production efficiency for Jersey-Holstein than for Holstein cows. However, previous studies have shown that breeding programs that have focused on milk yield have resulted in increased energy use efficiencies, especially during early lactation (van Arendonk et al., 1991; Veerkamp et al., 1994). Therefore, the results obtained in the present study indicated that crossbreeding of Holstein cows with Jersey sires had no negative effects on production efficiency.

The above results are supported by the evidence obtained in the present study that crossbreeding of Holstein cows with Jersey sires had no effects on energy efficiencies, in terms of energy digestibility and metabolizability. These values were almost identical between Holstein and Jersey-Holstein cows. Differences in energy efficiency between the 2 genotypes were also examined by development of a range of linear relationships using ME intake against HP or milk energy output, with energy metabolism data for each genotype derived from both high- and low-concentrate diets. With a common coefficient, no significant difference existed in the constants in any pair of the relationships between the 2 genotypes, indicating that cow genotype had little effect on the efficiency of ME use for production of milk and body tissue or the ratio of energy expenditure as a proportion of ME intake. The effects of cow genotype on energy efficiency were further evaluated in the present study by relating ME intake to the inefficiency of ME use for production of milk and body tissue, assuming no energy requirement for pregnancy and other functions (e.g., hair growth). With a common coefficient, the constant from Holstein cow data was not significantly different from that from Jersey-Holstein cow data. When the constant was forced to zero, the 

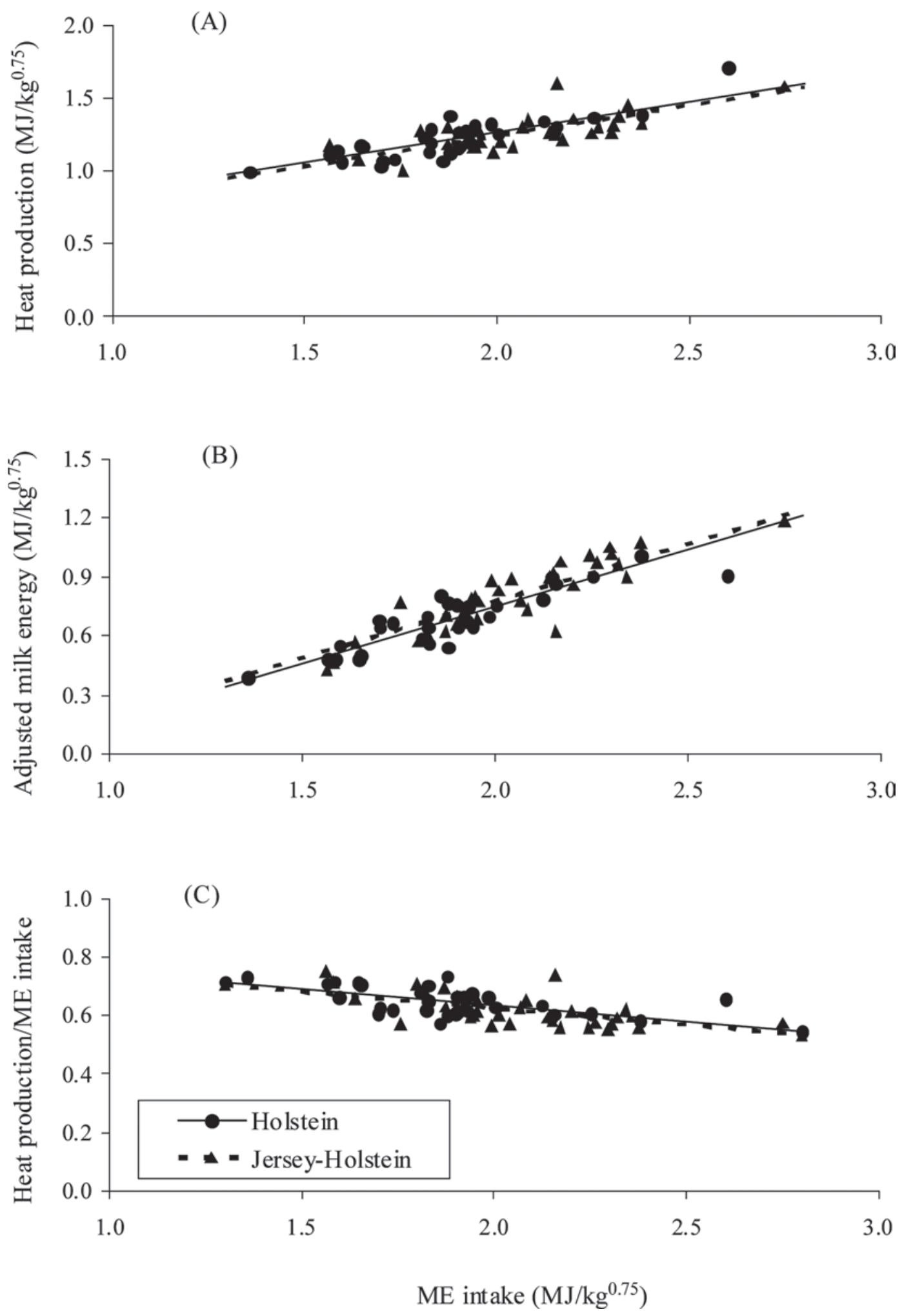

Figure 1. Relationships between ME intake and heat production (A), milk energy output adjusted to zero energy balance (B), and heat production as a proportion of ME intake (C) for Holstein and Jersey-Holstein crossbred cows. 
difference between $\mathrm{HP}$ and $\mathrm{ME}_{\mathrm{m}}$ was 0.30 of $\mathrm{ME}$ intake for both genotypes. Furthermore, the $\mathrm{ME}_{\mathrm{m}}$ values for Holstein and Jersey-Holstein cows are similar (0.71 vs. $\left.0.67 \mathrm{MJ} / \mathrm{kg}^{0.75}\right)$. These $2 \mathrm{ME}_{\mathrm{m}}$ values are marginally higher than those published recently (Agnew and Yan, 2000; Kebreab et al., 2003), but are within the range of 0.61 to 0.75 (average 0.67) reported by Yan et al. (1997) using a range of linear and multiple regression techniques. The high $\mathrm{ME}_{\mathrm{m}}$ values from both genotypes in the present study may be attributed to the fact that cows used in the present study were in the first lactation, which may have a higher metabolic rate than do older cows (Agnew and Yan, 2000).

When calculated from individual animal data from periods 1 to 4 (early to late lactation), no significant differences existed in the $k_{l}$ between Holstein and Jersey-Holstein cows, The mean $k_{l}$ value in the present study (0.581) was at the upper range (0.50 to 0.58 ) reported by Kebreab et al. (2003), but similar to values reported by Gordon et al. (1995b) and Kirkland and Gordon (1999; 0.58 and 0.59, respectively). Several previous studies have also found that $k_{l}$ was unaffected by cow genetic merit. Nayak and Maitra (1983) found that energy use efficiencies for milk production did not differ among 4 breeds of cows (Jersey, Holstein-Friesian, and Brown Swiss half-breeds with Haryana). Gordon et al. (1995b) and Ferris et al. (1999) reported that no difference existed in $k_{l}$ between high and medium merit Holstein cows. Yan et al. (2006) compared the energy efficiencies between Holstein and Norwegian cows during lactation wk 1 to 42 and found that cow genotype had no significant effect on $k_{l}$ value. Agnew and Yan (2000), in a review of calorimetric data of lactating dairy cows published by 2000 , reported that dietary and animal factors had little effect on $k_{l}$ values. Therefore, the results from the present study support the view that cow genotype has little effect on $k_{l}$ values of dairy cows. The crossbreeding of Holstein cows with Jersey sires does not alter the metabolic rate or the efficiency of ME use for milk production of Holstein cows.

Ample evidence indicates that within the same breed, high genetic merit cows have the ability to partition more energy into milk and less into body tissue than do low genetic merit cows (Veerkamp and Emmans, 1995; Agnew and Yan, 2000). Similar effects were reported by Tyrrell et al. (1990) and Yan et al. (2006) when comparisons were made between Holstein and Jersey, and Holstein and Norwegian dairy cows, respectively. Veerkamp et al. (1994) reported that, within the Holstein breed, high genetic cows had considerably higher milk energy output as a proportion of ME intake than did low genetic animals during the first $26 \mathrm{wk}$ of lactation. Yan et al. (2006) found that Holstein cows partitioned more energy into milk than did Norwegian cows during early to mid lactation, but the difference disappeared during late lactation. Bryant et al. (2003) reported that high genetic merit Jersey cows partitioned a significantly higher proportion of ME intake into milk than did low genetic merit Jersey cows in any stage of lactation. However, in the present study, no significant difference was found in milk energy output as a proportion of ME intake between Holstein and Jersey-Holstein cows, and cow genotypes also had no significant effects on energy partitioning into body tissue (energy balance/ME intake). Pryce et al. (1998) reported that high genetic merit cows with high milk production were associated with a high level of tissue energy loss. High genetic merit cows used more body reserves for milk production during early lactation (Bryant et al., 2003; Yan et al., 2006). However, the results obtained in the present study did not show any significant difference in energy retention between Jersey-Holstein cows and Holstein cows. The proportion of consumed ME used for tissue energy gain (energy retention/ME intake) was similar between Jersey-Holstein and Holstein cows. The results obtained in the present study indicated that crossbreeding of Holstein cows with Jersey sires did not alter energy partitioning between milk and body tissue.

\section{Effects of Stage of Lactation on Energy Use Efficiency}

The present study was also designed to examine the effects of stage of lactation on energy efficiencies within each cow genotype. To achieve this objective, silage was frozen during the early part of period 1 and the frozen silage offered during the energy metabolism measurements undertaken during each of periods 1 to 4 . This approach was adopted to overcome the potential effects on energy metabolism of offering silages of different qualities in early and late lactation. In order to minimize potential interactions between concentrate level and stage of lactation, the statistical comparison was undertaken using the pooled data for only 2 stages of lactation (i.e., early vs. late). The early lactation data set contained data obtained in the first 2 periods and the late lactation data set contained data for the second 2 periods. Thus, each data set contained data derived from both low and high concentrate levels for each cow. Energy metabolism data used in the present study were measured around wk 10, 16, 32, and 38 of lactation for periods $1,2,3$, and 4, respectively. The effects of stage of lactation on energy efficiencies are presented in Table 6. No significant effects of stage of lactation were found on energy digestibility and metabolizability or on dietary ME concentrations (ranging from 12.4 to $12.6 \mathrm{MJ} / \mathrm{kg}$ of $\mathrm{DM}$ ) within each genotype. Whereas 
Table 6. Effects of stage of lactation on energy intake and outputs and energy efficiency for Holstein and Jersey-Holstein dairy cows ${ }^{1}$

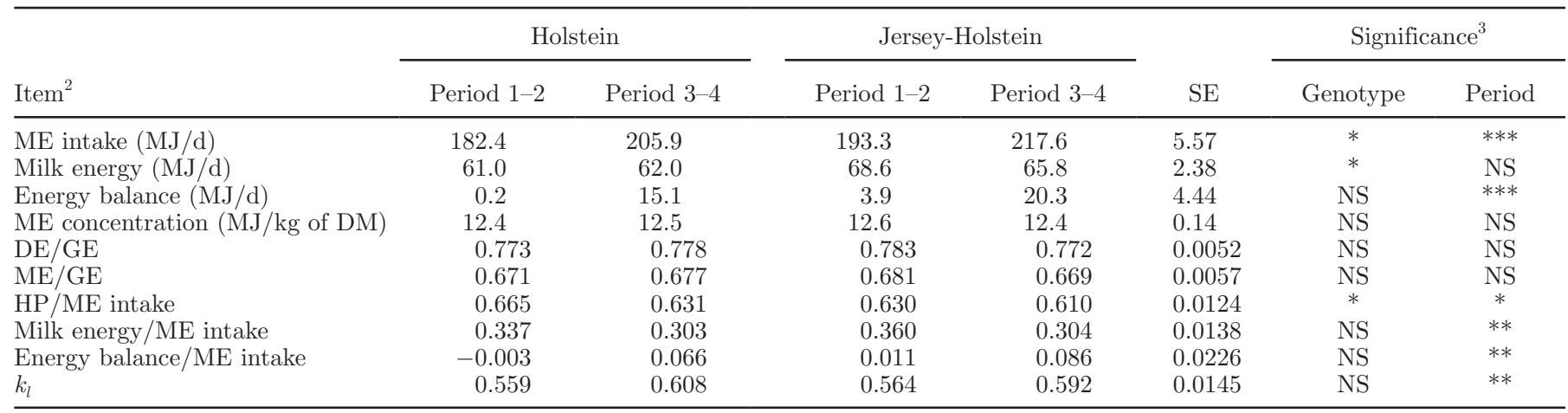

${ }^{1}$ Dietary concentrate level was used as block in the ANOVA for analysis of all variables.

${ }^{2} \mathrm{DE}=$ digestible energy; $\mathrm{GE}=$ gross energy; $\mathrm{HP}=$ heat production; $k_{l}=$ efficiency of $\mathrm{ME}$ use for lactation.

${ }^{3}$ No significant interaction existed for any variable between genotype and experimental period.

${ }^{*} P<0.05 ; * *<0.01 ; * * P<0.001$.

ME intake was significantly higher during late than during early stages of lactation within each genotype, the extra ME consumed was not used for milk production, but directed toward body tissue reserves. Moving from early to late lactation, the proportion of ME partitioned into milk (milk energy output/ME intake) decreased, whereas that partitioned into body tissue (energy balance/ME intake) increased $(P<0.01)$. A similar result was also reported by Yan et al. (2006) in a whole lactation study involving Holstein and Norwegian dairy cows. Veerkamp et al. (1994) and Veerkamp and Emmans (1995) reported that Holstein heifers were in positive energy balance after wk 8 (on average) of a 26 -wk study. In the present study, $k_{l}$ values significantly increased from early to late lactation $(P<0.01)$, and this was mainly due to a significantly higher HP as a proportion of ME intake in early lactation for both genotypes $(P<0.05)$. This result disagrees with that reported by Yan et al. (2006) who found that $k_{l}$ values remained similar from early to late lactation with both Holstein and Norwegian dairy cows.

\section{CONCLUSIONS}

Crossbreeding Holstein dairy cows with Jersey sires had no significant effect on the efficiency of ME use for lactation, irrespective of nutritional plane. The capacity of energy partitioning between milk and body tissue was also similar between Holstein and Jersey-Holstein dairy cows. These results indicate that the high milk production potential of Holstein cows can be maintained with crossbreeding programs using Jersey Sires, which have been widely adopted to improve the health and fertility of Holstein dairy cows.

\section{ACKNOWLEDGMENTS}

The authors thank the staff of the Dairy and Energy Metabolism Units (Agri-Food and Biosciences Institute, Hillsborough, Co. Down, UK) for collection of data and care of animals. This work was funded by the Department of Agriculture and Rural Development of Northern Ireland.

\section{REFERENCES}

Agnew, R. E., and T. Yan. 2000. The impact of recent research on energy feeding systems for dairy cattle. Livest. Prod. Sci. 66:197215 .

Agricultural and Food Research Council. 1990. Technical Committee on Responses to Nutrients, Report Number 5, Nutritive Requirements of Ruminant Animals: Energy. Nutr. Abs. Rev. (Series B) 60:729-804.

Auldist, M. J., M. F. S. Pyman, C. Grainger, and K. L. Macmillan. 2007. Comparative reproductive performance and early lactation productivity of Jersey $\times$ Holstein cows in predominantly Holstein herds in a pasture-based dairying system. J. Dairy Sci. 90:48564862.

Brouwer, E. (1965). Report of the sub-committee on constants and factors. Pages 441-443 in Energy Metabolism of Farm Animals. K. L. Blaxter, ed. European Association of Animal Production Publication No. 11. Academic Press, London, UK.

Bryant, J. R., N. Lopez-Villalobos, C. W. Holmes, G. D. Pitman, and I. M. Brookes. 2003. Effect of genetic merit on the estimated partitioning of energy towards milk production or liveweight gain by Jersey cows grazing on pasture. Proc. N.Z. Soc. Anim. Prod. 63:69-72.

Ferris, C. P., F. J. Gordon, D. C. Patterson, M. G. Porter, and T. Yan. 1999. The effect of genetic merit and concentrate proportion in the diet on nutrient utilization by lactating dairy cows. J. Agric. Sci. 132:483-490.

Frisch, J. E., and J. E. Vercoe. 1984. An analysis of growth of different cattle genotypes reared in different environments. J. Agric. Sci. (Camb.) 103:137-153.

Gordon, F. J., D. C. Patterson, T. Yan, M. G. Porter, C. S. Mayne, and E. F. Unsworth. 1995b. The influence of genetic index for milk production on the response to complete diet feeding and the utilization of energy and nitrogen. Anim. Sci. 61:199-210. 
Gordon, F. J., M. G. Porter, C. S. Mayne, E. F. Unsworth, and D. J. Kilpatrick. 1995a. Effect of forage digestibility and type of concentrate on nutrient utilization for lactating dairy cattle. J. Dairy Res. 62:15-27.

Hansen, L. B. 2000. Consequences of selection for milk yield from a geneticist's viewpoint. J. Dairy Sci. 83:1145-1150.

Heins, B. J., L. B. Hansen, and A. J. Seykora. 2006. Fertility and survival of pure Holsteins versus crossbreds of Holstein with Normande, Montbeliarde, and Scandinavian Red. J. Dairy Sci. 89:4944-4951.

Heins, B. J., L. B. Hansen, A. J. Seykora, A. R. Hazel, D. G. Johnson, and J. G. Linn. 2008. Crossbreds of Jersey $\times$ Holstein compared with pure Holsteins for body weight, body condition score, dry matter intake, and feed efficiency during the first one hundred fifty days of first lactation. J. Dairy Sci. 91:3716-3722.

Kebreab, E., J. France, R. E. Agnew, T. Yan, M. S. Dhanoa, J. Dijkstra, D. E. Beever, and C. K. Reynolds. 2003. Alternatives to linear analysis of energy balance data from lactating dairy cows. J. Dairy Sci. 86:2904-2913.

Kirkland, R. M., and F. J. Gordon. 1999. The metabolisable energy requirement for maintenance and the efficiency of use of metabolisable energy for lactation and tissue gain in dairy cows offered a straw/concentrate ration. Livest. Prod. Sci. 61:23-31.

Lucy, M. C. 2001. Reproductive loss in high-producing dairy cattle: Where will it end? J. Dairy Sci. 84:1277-1293.

Mackey, D. R., A. W. Gordon, M. A. McCoy, M. Verner, and C. s. Mayne. 2007. Associations between genetic merit for milk production and animal parameters and the fertility performance of dairy cows. Anim. 1:29-43.

Mayne, C. S., and F. J. Gordon. 1984. The effect of type of concentrate and level of concentrate feeding on milk production. Anim. Prod. 39:65-76.

Mulvany, P. M. 1977. Dairy Cow Condition Scoring. Paper 4468. Natl Inst. Res. Dairying, Reading, UK.

Nayak, J. B., and D. N. Maitra. 1983. Efficiency of nutrient utilization for milk production in cross-bred cows under hot and humid agroclimatic conditions. Indian J. Dairy Sci. 36:134-140.

Prendiville, R., K. M. Pierce, and F. Buckley. 2009. An evaluation of production efficiencies among lactating Holstein-Friesian, Jersey, and Jersey $\times$ Holstein-Friesian cows at pasture. J. Dairy Sci. 92:6176-6185.
Prendiville, R., K. M. Pierce, and F. Buckley. 2010. A comparison between Holstein-Friesian and Jersey dairy cows and their F-1 cross with regard to milk yield, somatic cell score, mastitis, and milking characteristics under grazing conditions. J. Dairy Sci 93:2741-2750

Pryce, J. E., R. J. Esslemont, R. Thompson, R. F. Veerkamp, M. A. Kossaibati, and G. Simm. 1998. Estimation of genetic parameters using health, fertility and production data from a management recording system for dairy cattle. Anim. Sci. 66:577-584.

Pryce, J. E., M. D. Royal, P. C. Garnsworthy, and I. L. Mao. 2004. Fertility in the high-producing dairy cow. Livest. Prod. Sci $86: 125-135$.

Schwager-Suter, R., C. Stricker, D. Erdin, and N. Künzi. 2001. Net energy efficiencies of Holstein, Jersey and Holstein-Jersey F1-crosses. Anim. Sci. 72:335-342.

Tyrrell, H. F., C. K. Reynolds, and H. D. Baxter. 1990. Energy metabolism of Jersey and Holstein cows fed total mixed diets with or without whole cottonseed. J. Dairy Sci. 73(Suppl. 1):192. (Abstr.)

Van Arendonk, J. A. M., G. J. Nieuwhof, H. Vos, and S. Korver. 1991. Genetic aspects of feed intake and efficiency in lactating dairy heifers. Livest. Prod. Sci. 29:263-275.

Veerkamp, R. F., and G. C. Emmans. 1995. Sources of genetic variation in energetic efficiency of dairy cows. Livest. Prod. Sci. 44:87-97.

Veerkamp, R. F., G. Simm, and J. D. Oldham. 1994. Effects of interaction between genotype and feeding system on milk production, feed intake, efficiency and body tissue mobilisation in dairy cows. Livest. Prod. Sci. 39:229-241.

Yan, T., R. E. Agnew, F. J. Gordon, and M. G. Porter. 2000. The prediction of methane energy output in dairy and beef cattle offered grass silage-based diets. Livest. Prod. Sci. 64:253-263.

Yan, T., F. G. Gordon, R. E. Agnew, M. G. Porter, and D. C. Patterson. 1997. The metabolisable energy requirement for maintenance and the efficiency of utilisation of metabolisable energy for lactation by dairy cows offered grass silage-based diets. Livest. Prod. Sci. 51:141-150.

Yan, T., C. S. Mayne, T. W. J. Keady, and R. E. Agnew. 2006. Effects of dairy cow genotype with two planes of nutrition on energy partitioning between milk and body tissue. J. Dairy Sci. 89:1031-1042 